\title{
Retinoblastoma-Associated Protein
}

National Cancer Institute

\section{Source}

National Cancer Institute. Retinoblastoma-Associated Protein. NCI Thesaurus. Code C17394.

Retinoblastoma-associated protein (928 aa, $106 \mathrm{kDa}$ ) is encoded by the human RB1 gene. This protein plays a role in the regulation of cell cycle progression. 